UDC 631.53.01:633.491

(C) 2016

Yu. Lavrynenko, Corresponding Member of the National Academy of Sciences of Ukraine, Doctor of Agricultural Sciences

G. Balashova, doctor of agricultural sciences

O Kotova.

Institute of Irrigated Agriculture of NAAS

\title{
CULTIVATION OF PLANTS OF POTATO IN VITRO AT MICROCLONAL REPRODUCTION
}

The purpose. To determine optimum root formation in crop in vitro of mediumearly cultivars of potato Nevskaya depending on acidity of nutrient medium $(\mathrm{pH})$, intensity of illumination and photoperiod for increaseof production of the initial improved planting stock. Methods. Complex use of laboratory, mathematical and statistical, calculation-comparative methods and system analysis. Results. Experimental data concerning influence of acidity of nutrient medium $(\mathrm{pH})$, intensity of illumination and photoperiod on induction of root formation are brought at microclonal reproduction of the improved initial material. It is fixed that $\mathrm{pH}$ of nutrient medium influences intensity of root formation. Conclusions. The maximum productivity indexes and economic efficiency of plants in vitro of medium-early cultivar Nevskaya are gained at $\mathrm{pH}=5,3$, photoperiod of $16 \mathrm{~h}$ and illumination of 2500 l. Intensity of root formation made 92,7\%, mass of average microtuber - 667,7 mg, mass of microtubers for 1 plant - 617,3 mg, amount of microtubers in mass more than $350 \mathrm{mg}-79,1 \%$ at profitableness of production of $117 \%$, cost prices $7,37 \mathrm{hrn} /$ microtuber, conditional net profit $8,63 \mathrm{hrn} /$ microtuber.

Key words: root formation, amount of interstitial sites, height of plants, acidity of nutrient medium, photoperiod, intensity of illumination, mass of microtubers.

The necessary basis for the development of the technology for obtaining microand minibools is the knowledge of the mechanism of tuber formation as a physiological and biochemical process and its methods of regulation. It is established that tuber formation in a plant is induced by a system of factors, :excess of assimilants, hormonal state of the plant, photoperiod, temperature decrease, nitrogen deficiency, change of tragacanth centers due to the damping of the activity of the apical meristem of the stalk in the direction of soboles and tubers, ontogenetic state of the plant $[1,2]$ 
[3]With the result that the process of tuber formation can be regulated by a number of endo- and exogenous factors, which are the basis for a number of micro and minitubers technologies in primary potato seed production, aimed at the longterm preservation of the reproductive properties of virus tested seed potatoes. [3] The success in cultivating cultures of cells, tissues and organs of plants is determined by the nutrient midst composition. $[4,5,6]$. For cultivating the potato culture the Murashige, Skoog (MS) [7] environments are used. They include macro- and micronutrients, iron, calcium, vitamins and growth stimulants. The acidity of this medium is important. It is known that in the native conditions a plant cell functions in the close variation limits of the hydrogen ions concentration. The relative stability of the $\mathrm{pH}$ value in the intracellular and environment of the cell is supported by buffer systems, in which the protein molecules play an essential role as ampholes. The structure and activity of biological macromolecules, preeminently proteins, especially enzyme proteins depend on the $\mathrm{Ph}$ value[4]. Also, the acidity of the medium determines the availability of nutrients for plants in vitro. . It is known that very acidic or alkaline media limit the flow of some elements as phosphorus and iron, making them relatively insoluble, limiting the growth of plants. At the same time, other elements with high acidity pass into the dissolved condition and become toxic to explants [9]. . It is very important that all processes go at a certain acidity. Especially it is necessary for biological catalysts as an enzymesthe to function properly(their activity can be sharply slowed down if they go through these limits). On the efficiency of the biotechnological method for obtaining qualitative source material is substantially influenced by other tuber factors formation such as the illumination intensity and the photoperiod affect on the efficiency of biotechnological method for receiving a qualitative source material. In such a way, investigation of above mentioned factors interaction is important for optimizing the process of potato tubers formation in vitro [6].

Purpose. The goal of the article is to determine the optimal mode of tuber formation in the culture in vitro medium early ripen potato variety Nevska, 
depending on the acidity of the nutrient midst $(\mathrm{pH})$, light intensity and photoperiod to increase the production of the original planting material disinfected.

Materials and research methods. The intensity of potato tuber formation of different varieties with the same acidity is different. The influence of the nutrient midst $\mathrm{pH}$ in interaction with the photoregulation over the Nevsky-type potato bulbous formation intansity in the culture in vitro was studied in the microclone laboratory. Three factors were put into the study: factor A - photoperiod (10 and 16 hours), factor B - light intensity (1500 and 2500 lux), factor C - acidity of the midst $(\mathrm{pH}=4.3,4.8,5.3)$. Studies were performed according to generally accepted methods. To obtain the healed potato plants in vitro outcomes by biotechnological method the method of thermo-chemotherapy in combination with the apical meristem culture was used, in accordance with "Methodological recommendations for research on potatoes" [5], methodological recommendations "Improvement of potato in culture in vitro" [8], " Optimization of methods of rehabilitation, reproduction and protection of seed potatoes against viral infection "[10] and" Biotechnological methods for the receipt and evaluation of healed potatoes "[3]. The experiments were carried out according to generally accepted methods [11, 12]. The economic production efficiency of recovered source material in culture in vitro was calculated based on the actual cost of microtubers according to technological maps.

Research results. During the observing the growth and development of plants, it was found that the average increase in plant height depended on the photoperiod. So, on the 20th cultivation day at sixteen-hour illumination the plants in vitro were higher averagely by $0,2 \mathrm{~cm}$ than at ten-hour (Table 1 ).

On the 40th day of observation the height growth of plants during the 16-hour photoperiod was also higher by $44.4 \%$ than at 10 hours and was $2.6 \mathrm{~cm}$. On the 20th and 40th day of cultivation the number of internodes was higher during the 16-hour photoperiod and averagely was , 4.1 and 5.8 pcs. vs 3.8 and 5.2 pcs. on 10hour illumination. Nevsky is a medium-sized potato variety. Therefore, on the 20th 
day of observation on the process of sixteen-hour lighting, only $5.1 \%$ of the microtubers were formed, but at the ten-hour - 3.6\%. On the 40th day of cultivation the photoperiod almost did not affect on the microtubers formation: $12.1 \%$ of plants formed microtubers at sixteen hours, and at ten - 12.8\%. During the interaction of the photoperiod and the intensity of the light, the height of the plants is almost the same in the 16-hours photoperiod on the 20th day -4.2 and $4.3 \mathrm{~cm}$ at 1500 and 2500 lux, respectively, and at 10 hours and 1500 lux increase was 4.6 $\mathrm{cm}$, which is $31.4 \%$ more than at 2500 lux. On the 40th day of cultivation the height growth of plants within the photoperiods is different. As a result, at 10 hours, it is $1.5 \mathrm{~cm}$ at 1500 lux, against $2.1 \mathrm{~cm}$ at 2500 lux. During the 16-hour photoperiod the height growth of plants amounted to 2.8 and $2.3 \mathrm{~cm}$ at 1500 and 2500 lux, respectively. On the 20th day of observations 5.3\% of microtubers were obtained against $1.9 \%$ at 1500 lux during the 10-hour photoperiod and at 2500 lux. At 16 hours - 4.6 and 5.7\%, respectively. On the 40th day of cultivation, the intensity of tuber formation is higher at a higher intensity of illumination. Thus, for ten hours and the intensity of light, 1500 lux was formed by $4.9 \%$ of microtubers it is less than at 2500 lux. At sixteen hours and in the illumination of 1500 lux $9.8 \%$ of plants formed microtubers, which is 1.5 times less than at the 2500 lux.

1.The acidity $(\mathrm{pH})$ Influence of the growing medium, photoperiod and quality of illumination on tuber formation of the Nevsky potato in the culture in vitro. 


\begin{tabular}{|c|c|c|c|c|c|c|c|c|c|c|c|c|}
\hline \multirow{4}{*}{ 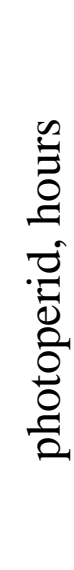 } & \multirow{4}{*}{ 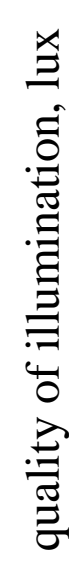 } & \multirow{4}{*}{ 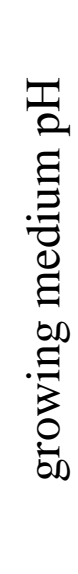 } & \multicolumn{10}{|c|}{ On the day of cultivation } \\
\hline & & & \multicolumn{4}{|c|}{ 20th } & \multicolumn{4}{|c|}{ 40th } & 60th & $\begin{array}{c}80 \mathrm{t} \\
\mathrm{h}\end{array}$ \\
\hline & & & \multirow{2}{*}{ 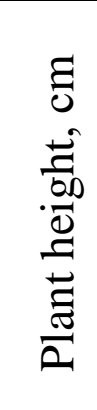 } & \multirow{2}{*}{ 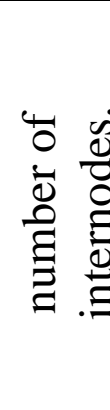 } & \multicolumn{2}{|c|}{$\begin{array}{l}\text { The number } \\
\text { of plants, } \\
\text { which } \\
\text { produced,\% }\end{array}$} & \multirow{2}{*}{ 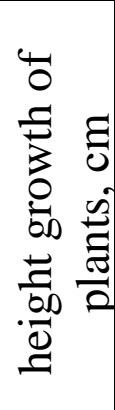 } & \multirow{2}{*}{ 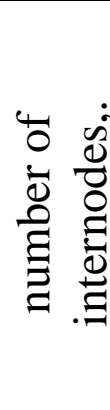 } & \multicolumn{4}{|c|}{$\begin{array}{l}\text { The number of plants, } \\
\text { which produced,\% }\end{array}$} \\
\hline & & & & & $\begin{array}{l}\mathscr{q} \\
\frac{0}{0} \\
\stackrel{0}{0}\end{array}$ & 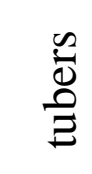 & & & 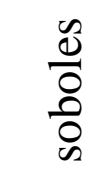 & 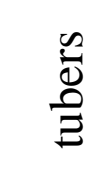 & $\begin{array}{l}\tilde{d} \\
\frac{n}{\Xi}\end{array}$ & 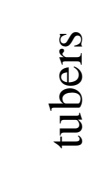 \\
\hline \multirow{6}{*}{10} & \multirow{3}{*}{ 용 } & 4,8 & 5,2 & 4,2 & 99,7 & 0,3 & 1,7 & 5,8 & 91,0 & 9,0 & 19,7 & 55,7 \\
\hline & & 4,3 & 4,3 & 3,9 & 98,3 & 1,7 & 1 & 5,1 & 92,7 & 7,3 & 14,0 & 30,0 \\
\hline & & 5,3 & 4,0 & 3,7 & 96,3 & 3,7 & 1,3 & 4,9 & 85,3 & 14,7 & 25,3 & 45,7 \\
\hline & \multirow{3}{*}{$\begin{array}{l}\text { 오 } \\
\text { N }\end{array}$} & 4,8 & 3,3 & 3,5 & 91,3 & 8,7 & 1,9 & 4,8 & 74,3 & 25,7 & 47,3 & 83,0 \\
\hline & & 4,3 & 3,5 & 3,9 & 95,0 & 5,0 & 2,3 & 5,5 & 91,7 & 8,3 & 9,3 & 59,7 \\
\hline & & 5,3 & 3,6 & 3,4 & 97,7 & 2,3 & 2,0 & 5,1 & 88,3 & 11,7 & 22,0 & 83,7 \\
\hline \multirow{6}{*}{16} & \multirow{3}{*}{ 음 } & 4,8 & 3,5 & 3,5 & 97,7 & 2,3 & 3,3 & 5,8 & 94,0 & 6,0 & 13,0 & 45,0 \\
\hline & & 4,3 & 4,9 & 4,4 & 95,0 & 5,0 & 2,7 & 6,4 & 90,7 & 9,3 & 19,3 & 49,7 \\
\hline & & 5,3 & 4,2 & 4,2 & 90,3 & 9,7 & 2,4 & 5,6 & 86,0 & 14,0 & 25,7 & 74,0 \\
\hline & \multirow{3}{*}{$\begin{array}{l}8 \\
\stackrel{2}{N}\end{array}$} & 4,8 & 4,5 & 4,3 & 98,7 & 1,3 & 2,4 & 6,0 & 90,7 & 9,3 & 28,0 & 76,7 \\
\hline & & 4,3 & 4,4 & 4,1 & 94,3 & 5,7 & 2,2 & 5,7 & 85,3 & 14,7 & 42,3 & 71,7 \\
\hline & & 5,3 & 3,9 & 3,8 & 93,3 & 6,7 & 2,3 & 5,4 & 81,0 & 19,0 & 43,7 & 92,7 \\
\hline
\end{tabular}

The nutrient medium acidity on the 20th and 40th day of observations slightly influenced over the height growth of plants and the number of internodes. On the 20th day the height growth of plants is 3.9; 4.3 and $4.1 \mathrm{~cm}(\mathrm{pH}=5.3,4.3,4.8)$; number of nodes $-3.8 ; 4.1$ and 3.9 pcs, respectively. On the 40th day the height growth of plants is 2,0; 2.2 and $2.3 \mathrm{~cm}$, respectively, and the number of internodes - 5.3; 5.7 and 5.6 pieces $(\mathrm{pH}=5.3,4.3,4.8)$. The tuber intensity on the 20th and 40th day of cultivation was higher at the medium $\mathrm{pH}$ of $5.3-5.6 \%$ and $14.8 \%$ vs. 4.3 and $9.9 \%$ and 3.2 and $12.5 \%$ at the $\mathrm{pH} 4.3$; 4.8. On the 60th day of observation, the best indicators of tuber formation during the 10- hours photoperiod and the intensity of illumination at 2500 lux and $\mathrm{pH}$ amount to $4.8-47.3 \%$, and at sixteen hours at 2500 lux illumination and $\mathrm{pH}$ to $5.3-43.7 \%$. On the 80th day of cultivation, the intensity of tuber formation has increased significantly. Thus, at ten 
hours of the photoperiod, 2500 lux and $\mathrm{pH}=5.3$, the tuber intensity was $84.0 \%$, and at sixteen hours, 2500 lux and $\mathrm{pH}=5.3-91.0 \%$. At 16 hours of the photoperiod, the mass of the average microtubers was $450.7 \mathrm{mg}$, the weight of microtubers on one plant was $320.0 \mathrm{mg}$, which is 2.1 and 2.2 times more than at the ten-hour photoperiod (Table 2). The tuber formation process was significantly influenced by the intensity of illumination. At 2500 lux, $77.9 \%$ of plants formed microtubers s vs $50.0 \%$ at 1500 lux. The mass of the average microtubers and the mass of microtubers per plant at 2500 lux illumination amounted to 387.9 and $308.2 \mathrm{mg}$, respectively, which is 108.8 and $151.9 \mathrm{mg}$ more than at $1500 \mathrm{lux}$, respectively. There was a significant difference between the bulb intensity, the mass of the average microtubers and the mass of microtubers per plant at various $\mathrm{pH}$ values in the nutrient midst. The lowest tuber formation intensity was observed at $\mathrm{pH} 4.3$ and amounted to $52.8 \%$, which was 12.3 and $21.2 \%$ lower than the acidity of 4.8 and 5.3, respectively. The experiment was noted the mass reduction of the average microtubers at the nutrient medium $\mathrm{pH}$ which is $4.3-262.7 \mathrm{mg}$ versus $298.5 \mathrm{mg}$ and $439.2 \mathrm{mg}$ at $\mathrm{pH} 4.8$ and 5.3, respectively. At a lower nutrient midst $\mathrm{pH}$ the mass of microtubers per plant was $148.4 \mathrm{mg}$, which is 43.5 and 208.0 mg less than at $\mathrm{pH} 4.8$ and 5.3, respectively. If we compare the tuber formation with different intensity of light, , the mass of the average microtuber within the ten-hour period of the photoperiod and at 2500 lux is 2.4 times more than at 1500 lux and amounts to $301.8 \mathrm{mg}$, but the mass of microtubers microtubers per plant at 2500 lux is 3, 6 times more than 1500 lux illuminate and amounts to $226.0 \mathrm{mg}$ (Fig. 1). In percentage terms, the tuber intensity at 2500 lux is $75.5 \%$ versus $43.8 \%$ at 1500 lux.

2.Productivity of Nevsky potato plants in the culture in vitro depending on the acidity of the nutrient midst(Ph), photoperiod and illumination intensity. 


\begin{tabular}{|c|c|c|c|c|c|c|c|}
\hline 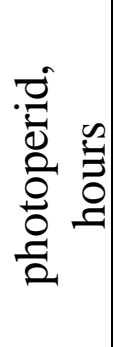 & 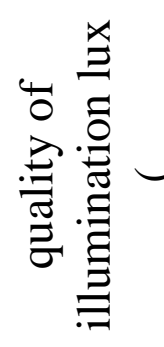 & 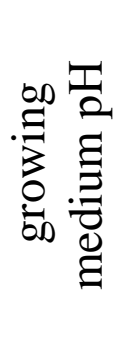 & 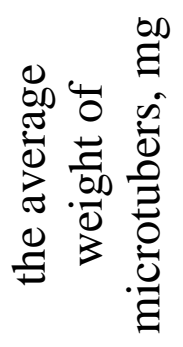 & 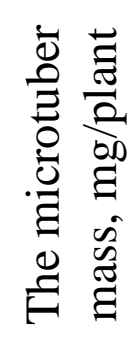 & 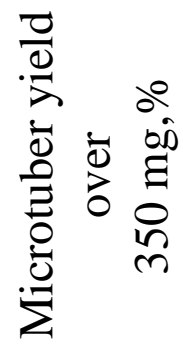 & 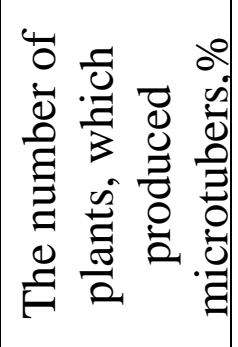 & 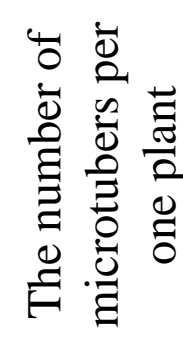 \\
\hline \multirow{6}{*}{10} & \multirow{3}{*}{1500} & 4,8 & 177,6 & 106,1 & 13,2 & 55,7 & 0,58 \\
\hline & & 4,3 & 96,3 & 29,2 & 0,0 & 30,0 & 0,30 \\
\hline & & 5,3 & 117,7 & 53,6 & 0,0 & 45,7 & 0,49 \\
\hline & \multirow{3}{*}{2500} & 4,8 & 185,1 & 152,6 & 10,0 & 83,0 & 0,81 \\
\hline & & 4,3 & 306,4 & 182,3 & 35,8 & 59,7 & 0,60 \\
\hline & & 5,3 & 413,9 & 343,0 & 54,6 & 83,7 & 0,84 \\
\hline \multirow{6}{*}{16} & \multirow{3}{*}{1500} & 4,8 & 384,7 & 171,1 & 46,0 & 45,0 & 0,45 \\
\hline & & 4,3 & 340,7 & 166,1 & 40,9 & 49,7 & 0,50 \\
\hline & & 5,3 & 557,3 & 411,5 & 71,6 & 74,0 & 0,72 \\
\hline & \multirow{3}{*}{2500} & 4,8 & 446,7 & 337,9 & 58,3 & 76,7 & 0,79 \\
\hline & & 4,3 & 307,3 & 215,8 & 34,9 & 71,7 & 0,70 \\
\hline & & 5,3 & 667,7 & 617,3 & 79,1 & 92,7 & 0,91 \\
\hline
\end{tabular}

Within the photoperiods of medium influences the $\mathrm{pH}$ influences the tuber formation. At 10 hours, the average weight of microtubers amounted to 5.3 is $265.8 \mathrm{mg}$, which is 84.4 and $64.4 \mathrm{mg}$ more than at $\mathrm{pH} 4.8$ and 4.3, respectively. At 16 hours the mass of the average microtubers at a $\mathrm{pH}$ of $5.3-612.5 \mathrm{mg}$ versus $415.7 \mathrm{mg}$ and 324.0 units. at $\mathrm{pH} 4.8$ and 4.3, respectively. The mass of microtubers per plant at 10 hours is significantly higher at pH 5.3- $198.3 \mathrm{mg}$, which is 68.9 and $92.5 \mathrm{mg}$ more than at $\mathrm{pH} 4.8$ and 4.3. During the 16-hours photoperiod at $\mathrm{pH} 5.3$, the mass of microtubers per plant is $514.4 \mathrm{mg}$, which is 2.0 and 2.7 times higher than at $\mathrm{pH} 4.8$ and 4.3 . 


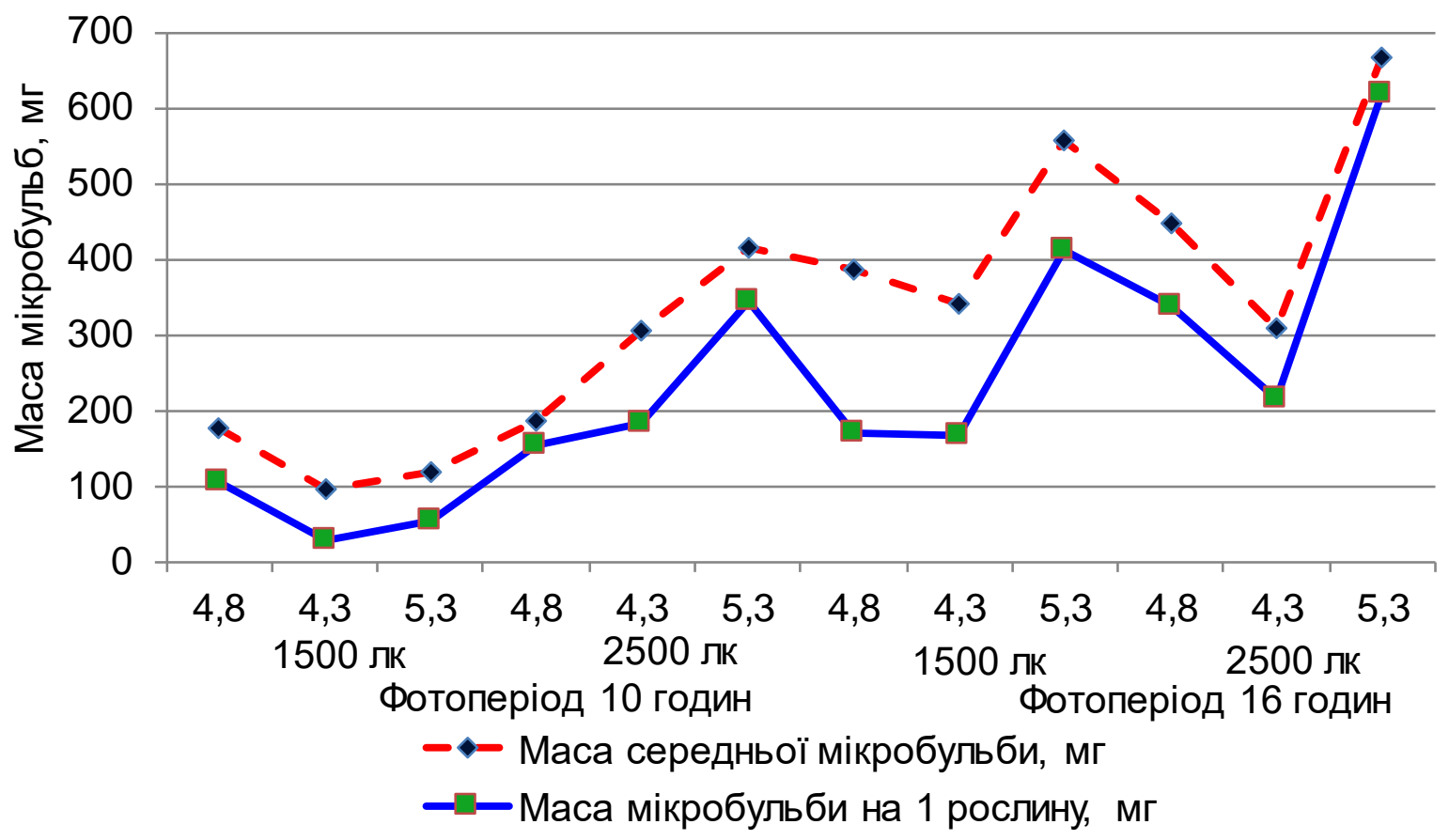

Pict. 1 The Influence of nutrient medium photoregulation and acidity on the microtubers formation of the Nevsky potato variety in the culture in vitro.

The cost of one microtubers in applying sixteen-hour illumination increases by $16.0 \%$, compared with ten hours, on average by factor (Table 3). Using the intensity of the illumination of 2500 lux during the plant in vitro cultivation the cost was reducted by $35.6 \%$, while at $\mathrm{pH}$ of the nutrient midst it was 8.7 and 29.7\% lower than at $\mathrm{pH} 4.8$ and 4,3.

Conclusions. Maximum indices of productivity and economic efficiency of middle-class Nevsky plants in vitro were obtained at $\mathrm{pH}=5.3$; also during the 16 hour photoperiod and illumination 2500 lux: the tuber formation intensity was $92.7 \%$, the weight of the average microtubers - $667.7 \mathrm{mg}$, the mass of microtubers per plant - $617.3 \mathrm{mg}$, the number of microtubers weighing more than $350 \mathrm{mg}$ $79.1 \%$ with the profitability of production $117 \%$, the cost of $7.37 \mathrm{UAH} /$ microtubers, the conditional net profit was 8.63 UAH / microtubers.

3. Growing productivness of the Middle Class Nevsky potatoes microtubers in the culture in vitro depending on photoregulation and acidity of the nutrient midst. 


\begin{tabular}{|c|c|c|c|c|c|c|c|}
\hline 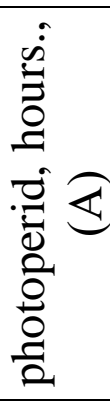 & $\begin{array}{l}\text { quality of } \\
\text { illuminati } \\
\text { on lux (B) }\end{array}$ & $\begin{array}{l}\text { growin } \\
\text { g } \\
\text { mediu } \\
\text { m pH } \\
\text { (C) }\end{array}$ & $\begin{array}{l}\text { The } \\
\text { number of } \\
\text { microtube } \\
\text { rs per one } \\
\text { plant }\end{array}$ & $\begin{array}{c}\text { Cost } \\
\text { s per } \\
\text { plant } \\
\text { ' } \\
\text { UA } \\
\text { N }\end{array}$ & $\begin{array}{c}\text { Prime } \\
\text { cost, } \\
\text { UAN / } \\
\text { microtub } \\
\text { er }\end{array}$ & $\begin{array}{c}\text { condition } \\
\text { al net } \\
\text { profite or } \\
\text { loss, } \\
\text { UAN / } \\
\text { microtub } \\
\text { er }\end{array}$ & $\begin{array}{c}\text { profitabilit } \\
\text { y, \% }\end{array}$ \\
\hline \multirow{6}{*}{10} & \multirow{3}{*}{1500} & 4,8 & 0,56 & 6,00 & 10,71 & 5,29 & 49 \\
\hline & & 4,3 & 0,30 & 6,10 & 20,33 & $-4,33$ & -21 \\
\hline & & 5,3 & 0,46 & 6,20 & 13,48 & 2,52 & 19 \\
\hline & \multirow{3}{*}{2500} & 4,8 & 0,83 & 6,35 & 7,65 & 8,35 & 109 \\
\hline & & 4,3 & 0,60 & 6,45 & 10,75 & 5,25 & 49 \\
\hline & & 5,3 & 0,84 & 6,55 & 7,80 & 8,20 & 105 \\
\hline \multirow{6}{*}{16} & \multirow{3}{*}{1500} & 4,8 & 0,45 & 6,30 & 14,00 & 2,00 & 14 \\
\hline & & 4,3 & 0,50 & 6,40 & 12,80 & 3,20 & 25 \\
\hline & & 5,3 & 0,74 & 6,50 & 8,78 & 7,22 & 82 \\
\hline & \multirow{3}{*}{2500} & 4,8 & 0,77 & 6,65 & 8,64 & 7,36 & 85 \\
\hline & & 4,3 & 0,72 & 6,75 & 9,38 & 6,63 & 71 \\
\hline & & 5,3 & 0,93 & 6,85 & 7,37 & 8,63 & 117 \\
\hline
\end{tabular}

\section{Bibliography}

1. Chaylakhyan M.Kh. Mekhanyzmы klubneobrazovanyya u rastenyy kartofelya/M.Kh. Chaylakhyan//Rehulyatsyya rosta y razvytyya kartofelya. — M.: Nauka, 1990. - S. 48 - 62.

2. Awan A.R. In vitro elimination of potato leaf roll polerovirus from potato varieties/A.R. Awan, S.M. Mughal//European J. of Scientific Research. — 2007. - V. 18. - \# 1. - P. 155 - 164.

3. Byotekhnolohycheskye metodы poluchenyya y otsenky ozdorovlennoho kartofelya: metod. rekom.; podhot.: L.N. Trofymets, V.B. Boyko, T.V. Zeyruk [y dr.]. - M., 1988. — 37 s.

4. Kalynyn F.L. Metodы kul'turы tkaney v fyzyolohyy y byotekhnolohyy rastenyy/F.P. Kalynyn, V.V. Sarnatskaya, V.Э. Polyshchuk. - K.: Nauk. dumka. - 1980. - S. 27 - 28. 
5. Metodychni rekomendatsiyi shchodo provedennya doslidzhen' z kartopleyu; pidhot.: V.S. Kutsenko, A.A. Osypchuk, A.A. Podhayets'kyy [ta in.]/Nemishayeve: In-t kartoplyarstva, 2002. - $183 \mathrm{~s}$.

6. Melyk-Sarkysov O.S. Yspol'zovanye эffekta klubneobrazovanyya $\mathrm{v}$ byotekhnolohyy kartofelevodstva/O.S. Melyk-Sarkysov, Y.Y. Fadeeva//Vestn. s.kh. nauky. - 1989. — \# 9. — S. 86 - 91.

7. Murashige T. A revised medium for rapid growth and bioassays with tobacco tissue cultures/T. Murashige, F. Skoog//Physiol. Plant. — 1962. — V. 15. — P. $473-497$.

8. Sovershenstvovanye vyrusolohycheskoho kontrolya $\mathrm{v}$ protsesse formyrovanyya y podderzhanyya banka zdorovыkh sortov kartofelya/B.V. Anysymov, E.V. Ovэs, O.V. Topysheva [y dr.]//Kartofelevodstvo: materyalы nauch.-prakt. konf., posvyashch. 120-letyyu so dnya rozhdenyya A.H. Lorkha/RASKhN, VNYYKKh; pod red. E.A. Symakova. — M., 2009. — S. 188 - 192.

9. Klonal'noe mykrorazmnozhenye rastenyy: uch.-metod. posobye/O.A.

Tymofeeva, Yu.Yu. Nevmerzhytskaya. — Kazan': Kazanskyy un-t, 2012. — 56 s. 10. Optymyzatsyya pryemov ozdorovlenyya, razmnozhenyya y zashchytы semennoho kartofelya ot vyrusnoy ynfektsyy: metod. ukazanyya. - Mynsk: BelNYYZR, 1996. - $16 \mathrm{~s}$.

11. Metodyka pol'ovykh i laboratornykh doslidzhen' na zroshuvanykh zemlyakh/R.A. Vozhehova, Yu.O. Lavrynenko, M.P. Malyarchuk ta in.; za red. R.A. Vozhehovoyi. — Kherson: In-t zrosh. zemlerob., 2014. — 286 s.

12. Bondarchuk A.A. Naukovi osnovy nasinnytstva kartopli v Ukrayini/A.A. Bondarchuk. — Bila Tserkva, 2010. — 400 s. 